\title{
Job security and the promotion of workers' wellbeing in the midst of the COVID-19 pandemic: A study with Canadian workers one to two weeks after the initiation of social distancing measures
}

\author{
Tyler Pacheco $\cdot$ Simon Coulombe $\cdot$ Christine Khalil $\cdot$ Sophie Meunier $\cdot$ Marina Doucerain $\cdot$ \\ Emilie Auger · Emily Cox
}

\begin{abstract}
Background: Due to the current coronavirus (COVID-19) crisis, workplaces have had to make significant alterations in the way they conduct business. This, in addition to the current financial instability, may put workers at risk of experiencing job insecurity and, in turn, lower wellbeing. Job insecurity is a key determinant of wellbeing, but little is known on how it is impacted by public health crises, and more specifically how it relates to workers' positive and negative wellbeing in the midst of a pandemic. Research is lacking on resilience levers that workplace interventions should target to support wellbeing in times of insecurity. Objective: Framed from a multidisciplinary perspective (public health, positive and organizational psychology), the study explores (1) workers' job (in)security during the COVID-19 pandemic one to two weeks after social distancing measures were implemented by Canadian governments, (2) how job (in)security relates to wellbeing during the pandemic, and (3) the potential positive effects of workplace-related resilience levers. Method: 1,073 Canadian workers working full-/part-time or who were temporarily laid off completed an online survey, including measures of wellbeing at work or in general, job security and potential resilience levers (workplace disaster preparedness, policy, social capital). Results: Multiple regression findings highlight that marginalized workers (e.g., women, migrants, people facing financial hardships) reported lower job security, and having temporarily lost one's job was negatively associated with job security. Low job security was related to lower scores across measures of wellbeing. Distress was high in the sample. Workplace disaster preparedness, policy and social capital were associated with higher wellbeing. The effects of these resilience levers tended to be stronger at higher job security levels. Discussion: Recommendations include a systemic, collaborative approach that includes policies fostering job security as well as resilience-promoting interventions in the workplace to protect/increase the wellbeing of workers during COVID-19.
\end{abstract}

Keywords: COVID-19, coronavirus, wellbeing, workplace, job security, resilience, Canada 


\section{Practice implications}

- Systemic changes are needed to support communities (e.g., women, migrants) who are often marginalized in the workplace, and who are now experiencing a higher degree of job insecurity during COVID-19.

- Establishing ways of improving job security and reassuring workers about employment stability could increase the effectiveness of workplace interventions to foster workers' resilience in the context of COVID-19.

- Multidisciplinary effort between experts, decision-makers and professionals from diverse fields is recommended in order to support the holistic wellbeing of workers.

\section{Introduction}

The coronavirus (COVID-19) crisis has resulted in challenges for workers' job security (Carter \& May, 2020; Sanchez et al., 2020; Statistics Canada, 2020b). In Canada, governments have established policies to contain the pandemic's outbreak, and these policies are inadvertently impacting labour market activities (Statistics Canada, 2020b). Data from the March Labour Force Survey revealed that millions of Canadians suffered job loss or a reduction in their usual work hours, creating concerns related to continued job security (Statistics Canada, 2020b). The role of job (in)security in the wellbeing of workers during pandemics and similar crises has been overlooked in the literature. Furthermore, little guidance is available on how resilience levers (i.e., supervision, support and policies; organizational preparedness to the crisis) may promote worker's wellbeing in the context of the COVID-19 crisis. This study seeks to address these gaps.

\section{Literature review}

Job security refers to "employee's expectations about the stability and longevity of their job in an organization" (Lu et al., 2017, p. 30). Research shows that natural disasters and public health crises impose negative economic impacts (Qin \& Jiang, 2011; Mastroianni, 2009). Following the Wenchaun Earthquake in China, private enterprises suffered major economic damage (Qin \& Jiang, 2011). Data from survivors of the earthquake revealed that their sense of job insecurity significantly increased (Qin \& Jiang, 2011). During the Severe Acute Respiratory Syndrome (SARS) crisis, workers in Toronto suffered economic costs associated with social isolation measures (i.e., quarantine), including layoffs and loss of income (Gupta et al., 2005). In light of the current COVID-19 crisis, there has been global fears related to a potential economic recession (Nicola et al., 2020). Negative economic impacts (e.g., disruptions in supply chains, loss of income, layoffs) are already evident in several industries, including primary, secondary and tertiary sectors. Researchers have suggested that job insecurity is a potential stressor experienced during the COVID-19 crisis, which could lead to decreased wellbeing (Holmes et al., 2020; Zhou et al., 2020; Wilson et al., 2020).

Job insecurity has indeed consistently been associated with decreased wellbeing in previous literature (Witte, 2010). From a public health perspective, job (in)security is considered to be a key determinant of wellbeing ${ }^{1}$ (Blacker et al., 2020; Wilkinson \& Marmot, 2003). Job insecurity

\footnotetext{
${ }^{1}$ We recognize that terms such as health, mental health, wellbeing and quality of life are used somewhat interchangeably (Keyes, 2006; Tennant et al., 2007; Veenhoven, 2000). While the phrase "determinants of health" rather than "of wellbeing" is often used in the public health literature, we privilege the term wellbeing in the present article in order to adopt a more multidimensional focus aligned with conceptualizing wellbeing as "the integration of a person's physical, mental, emotional, spiritual and social characteristics" (Law, Steinwender, \& Leclair, 1998, p. 83). Although not all these aspects of wellbeing could be measured in our study, from a theoretical standpoint, we adhere to such a holistic view on the nature of human wellbeing.
} 
negatively affects wellbeing because of financial instability and the threat to many social benefits derived from work (e.g., social status, social network) (Fullerton, McCollum, Dixon, \& Freeman, 2020; Jahoda, 1982; Selenko \& Batnic, 2013). Job insecurity may also lead to increased dissatisfaction with work as well as absenteeism (Qin \& Jiang, 2011).

According to trends from the severe acute respiratory syndrome (SARS) outbreak, marginalized people may experience the most job insecurity during a pandemic (Van Wagner, 2018). For example, three Chinatowns in Toronto experienced the greatest economic challenges during the SARS outbreak due to stigma arising from fear that the virus was spreading in these communities, leading others to avoid these areas (Van Wagner, 2018). In the same context, job insecurity was common amongst low-income workers with limited job protection rights, such as those working in the hospitality industry (Rothstein \& Coughlin, 2019; Van Wagner, 2018). A recent survey on COVID-19 showed that LGBTQ Americans may be facing more economic hardships (i.e., job loss, wage reduction) compared to the general population (Mckay et al., 2020). These studies are in line with the literature reviewed by Landsbergis, Grzywacz and Lamontagne (2014) which highlights that women, people from lower socio-economic status, and migrants tend to be more at risk for higher job insecurity, thereby contributing to wellbeing disparities.

Given the novel nature of COVID-19, limited research has been published on the impacts of job (in)security on workers' wellbeing, especially during the crisis' early stages when people were adjusting to numerous life changes while becoming aware of the threat to their job security. Inspired by positive (Keyes, 2002, 2005) and organizational psychology (Fisher, 2014) literature, we define wellbeing as a "broad category that encompasses a number of workplace factors" (Harter, Schmidt, \& Keyes, p. 206), encompassing both the presence of positive functioning, and the absence of negative functioning. Example indicators associated with workers' wellbeing (or lack thereof) include distress, mental health symptoms and how these affect work performance (i.e., presenteeism, Cooper \& Dewe, 2008). Indicators can also include positive perceptions of actualizing one's potential or thriving at work (Dagenais-Desmarais \& Savoie, 2012). Wellbeing at work and wellbeing in life more generally influence each other, underlining the importance of considering workers' wellbeing holistically (Steel, Schmidt, Bosco, \& Uggerslev, 2019). This is crucial in the current COVID-19 context where the frontiers between work and home have been blurred by increased pressures to work remotely (Jones, 2020).

In challenging workplace conditions, some workers may show resilience, i.e., "ways of feeling, thinking, and behaving that can allow for recuperative functioning" (McLarnon \& Rothstein, 2013 p. 65). Workers are nested within multilevel systems (Bone, 2015) and as such, resilience is not only dependent on individuals, but also on environmental opportunities and resources. To our knowledge, research has not examined the organizational resilience factors that may buffer the negative effects of the COVID-19 crisis on wellbeing. It is essential to identify resilience factors that managers, employers and public health leaders could leverage in the recovery phase of the COVID-19 crisis, as well as in preparation for future crises. We consider three resilience levers:

1) Workplace disaster preparedness: According to the World Health Organization (WHO), employers should draft emergency plans in the workplace to "effectively anticipate, respond to, and recover from the impacts of likely, imminent, emerging, or current emergencies." (WHO, 2017, p. 14). This may involve anticipating emergencies and training employees on emergency response protocols (Perry et al., 2001, p. 1-7), or providing information about leave policies, telecommuting options, and wage compensation plans (Benson \& Dix, 2009; see also Fung et al., 2008). A recent literature 
review suggests that maintaining communication in organizations may help buffer the negative effects of the COVID-19 pandemic on worker wellbeing (Hamouche, 2020).

2) Supportive workplace policies: During the SARS epidemic, job protection policies in Ontario, Canada, such as income-replacement legislations helped reduce job insecurity, thereby improving workers' wellbeing (Rothstein \& Coughlin, 2019). Studies have recommended resilience programs to educate workers on coping with pandemicassociated stressors (Aiello et al., 2010; Maunder et al., 2010). This aligns with the demonstrated benefit of facilitating access to wellness programs and providing benefit packages (Attridge, 2012). Such programs may be especially useful for people with limited financial means for out-of-pocket counselling.

3) Social capital: This refers to positive relations with colleagues and supervisors, characterized by trust and reciprocity, and it is associated positively with workers' health and wellbeing (Kouvonen et al., 2006). Personal social capital - in a community context was associated with positive impacts on wellbeing for individuals self-isolating at home during the COVID-19 pandemic (Xiao et al., 2020); however, no research was found on social capital specific to the workplace in the current context.

The objectives of this study are to investigate (1) diverse workers' sense of job (in)security during the COVID-19 pandemic between one and two weeks after social distancing measures were implemented, (2) how job (in)security relates to wellbeing during the pandemic, and (3) the potential positive effects of workplace-related resilience levers.

\section{Methods}

\section{Participants}

The sample consists of 1,122 adults living in Canada, working at least 20 hours per week at the time of the study (or were working at least 20 hours per week prior to the COVID-19 crisis), and able to understand and speak English. Given the study's focus on current job stability, 49 participants were not included in the analysis as they were not working at the time of the survey and would not be regaining the same job they had before COVID-19. Of the final sample used in the presented article's analysis, most workers resided in Ontario (47.7\%) and were working fulltime $(71.4 \%)$ at the time of the study. The sample included numerous workers from marginalized groups identifying as: non-heterosexual (i.e., minority sexual orientation, $21.3 \%$ ), gender nonbinary $(2.3 \%)$, transgender $(1.2 \%)$, living with a disability $(17.3 \%)$, people of colour $(9.0 \%)$, and/or not born in Canada (14.6\%). A full breakdown of the demographics regarding the final sample can be found in Table 1. 
Table 1.

Characteristics of workers surveyed $(N=1073)$.

\begin{tabular}{|c|c|c|c|}
\hline Variables & Frequency $(\mathrm{n})$ & Percentage $(\%)$ & Missing: $\mathrm{n}(\%)$ \\
\hline \multicolumn{4}{|l|}{ Age in years } \\
\hline \multicolumn{4}{|l|}{$39.66 \pm 12.09($ Mean \pm SD $)$} \\
\hline \multicolumn{4}{|l|}{ Gender identity } \\
\hline Women & 794 & 74.0 & \\
\hline Men & 246 & 22.9 & \\
\hline Non-binary & 25 & 2.3 & $8(0.7)$ \\
\hline \multicolumn{4}{|l|}{ Sexual orientation } \\
\hline Heterosexual & 823 & 76.7 & \\
\hline Minority sexual orientation & 229 & 21.3 & $21(2.0)$ \\
\hline \multicolumn{4}{|l|}{ Diagnosed or living with a disability } \\
\hline Yes & 186 & 17.3 & \\
\hline No & 872 & 81.3 & $15(1.4)$ \\
\hline \multicolumn{4}{|l|}{ Identifies as transgender } \\
\hline Yes & 13 & 1.2 & \\
\hline No & 1049 & 97.8 & $11(1.0)$ \\
\hline \multicolumn{4}{|l|}{ Identifies as a person of colour } \\
\hline Yes & 97 & 9.0 & \\
\hline No & 957 & 89.2 & $19(1.8)$ \\
\hline \multicolumn{4}{|l|}{ Residing province/territory } \\
\hline Alberta & 119 & 11.1 & \\
\hline British Columbia & 144 & 13.4 & \\
\hline Manitoba & 47 & 4.4 & \\
\hline New Brunswick & 41 & 3.8 & \\
\hline Newfoundland and Labrador & 21 & 2.0 & \\
\hline Northwest Territories & 2 & 0.2 & \\
\hline Nova Scotia & 82 & 7.6 & \\
\hline Nunavut & 0 & 0.0 & \\
\hline Ontario & 512 & 47.7 & \\
\hline Prince Edward Island & 3 & 0.3 & \\
\hline Quebec & 56 & 5.2 & \\
\hline Saskatchewan & 42 & 3.9 & \\
\hline Yukon & 3 & 0.3 & $1(0.1)$ \\
\hline \multicolumn{4}{|l|}{ Born in Canada } \\
\hline Yes & 916 & 85.4 & \\
\hline No & 157 & 14.6 & $0(0.0)$ \\
\hline \multicolumn{4}{|l|}{ Highest achieved educational level } \\
\hline Did not graduate from high school & 17 & 1.6 & \\
\hline High school graduate & 92 & 8.6 & \\
\hline Some college/trade school & 75 & 7.0 & \\
\hline College/trade school graduate & 227 & 21.2 & \\
\hline Some university & 100 & 9.3 & \\
\hline University (Bachelor's degree) & 363 & 33.8 & \\
\hline $\begin{array}{l}\text { University (Graduate or professional } \\
\text { degree) }\end{array}$ & 198 & 18.5 & $1(0.1)$ \\
\hline \multicolumn{4}{|l|}{ Number of people living in household } \\
\hline $2.48 \pm 1.23($ Mean $\pm \mathrm{SD})$ & & & \\
\hline
\end{tabular}

(continued on next page) 


\begin{tabular}{|c|c|c|c|}
\hline Variables & Frequency $(\mathrm{n})$ & Percentage (\%) & Missing: $\mathrm{n}(\%)$ \\
\hline \multicolumn{4}{|l|}{$\begin{array}{l}\text { Household income situation (Okechukwu, } \\
\text { El Ayadi, Tamers, Sabbath, \& Berkman, } \\
\text { 2012) }\end{array}$} \\
\hline Comfortable with extra & 381 & 35.5 & \\
\hline Enough but no extra & 407 & 37.9 & \\
\hline Have to cut back & 134 & 12.5 & \\
\hline Cannot make ends meet & 40 & 3.7 & $111(10.3)$ \\
\hline \multicolumn{4}{|l|}{$\begin{array}{l}\text { Employment status during COVID-19 } \\
\text { (more than one could be selected) }\end{array}$} \\
\hline Employed full-time (30+ hours/week) & 766 & 71.4 & \\
\hline Employed part-time (10-29 hours/week) & 124 & 11.6 & \\
\hline $\begin{array}{l}\text { Laid off temporarily (contract on hold } \\
\text { and/or return is expected to the same } \\
\text { employment after the crisis is resolved) }\end{array}$ & 201 & 18.7 & $0(0.0)$ \\
\hline \multicolumn{4}{|l|}{$\begin{array}{l}\text { Industry of employment (Workplace Safety } \\
\text { and Insurance Board, 2018) }\end{array}$} \\
\hline Agriculture & 11 & 1.0 & \\
\hline Automotive & 21 & 2.0 & \\
\hline Chemicals/processinga & 1 & 0.1 & \\
\hline Construction & 25 & 2.3 & \\
\hline Education & 134 & 12.5 & \\
\hline Electrical & 4 & 0.4 & \\
\hline Food & 83 & 7.7 & \\
\hline Forestrya & 1 & 0.1 & \\
\hline Health care & 212 & 19.8 & \\
\hline Manufacturing & 55 & 5.1 & \\
\hline Mining & 6 & 0.6 & \\
\hline Municipal services & 25 & 2.3 & \\
\hline Primary metals ${ }^{\mathrm{a}}$ & 1 & 0.1 & \\
\hline Pulp \& paper & 0 & 0.0 & \\
\hline Services & 138 & 12.9 & \\
\hline Transportation & 34 & 3.2 & \\
\hline Other & 402 & 37.5 & $0(0.0)$ \\
\hline
\end{tabular}

aThese categories were merged with "Other" for the regression analysis.

\section{Procedure}

The study was approved by the Wilfrid Laurier University's Research Ethics Board (REB \#6497). Participants were recruited through paid and unpaid Facebook advertisements and a panel of workers was also assembled by Qualtrics. Participants who met the inclusion criteria were directed to Qualtrics' secure platform to share their experiences one to two weeks after distancing measures were instated, i.e., between March 20th and 29th, 2020. The survey included several attention check questions to ensure fraudulent responders were screened out of the final sample. After completing the survey, those recruited through Facebook were given the option to enter a raffle for multiple $\$ 50$ dollar e-gift cards. Members of the panel were compensated through rewards offered by their panel company.

\section{Measures}

\section{Job Security}

Seven items with the highest factorial loading from Kraimer, Wayne, Liden, and Sparrowe's (2005) job security perceptions scale were used. The items (e.g., "I will be able to keep my present 
job as long as I wish.") are answered on a seven-point scale ranging from 1 (strongly disagree) to 7 (strongly agree) $(\alpha=.86)$.

\section{Wellbeing Outcomes}

Troublesome symptoms at work and impaired productivity. This was measured using Lam, Michalak, and Yatham's (2009) Employment Absence and Productivity Scale consisting of two subscales assessing troublesome symptoms workers may experience and impairment to their productivity over the past week. The seven items (e.g., "low energy or motivation," "getting less work done") are measured on a five-item scale ranging from $0 \%$ (none of the time) to $100 \%$ (all of the time) ( $\alpha=.87$ and .84 , for each subscale respectively).

Thriving at work. The five items from Dagenais-Desmarais and Savoie's (2011) Thriving at Work subscale of the Index of Psychological Well-Being at Work (IPWBW) scale was used. The items are measured on a six-point scale ranging from 0 (disagree) to 5 (completely agree) $(\alpha=.95)$. Workers are asked to reflect on these statements (e.g., "I like my job," "I find my job exciting") in the context of the last four weeks.

Psychological distress. Kroenke, Spitzer, Williams, and Löwe's (2009) Patient Health Questionnaire-4 (PHQ-4) was used to assess the level of anxiety and depression experienced in the last week. The measure has four items (e.g., "feeling down, depressed or hopeless") which are answered on a four-item scale ranging from 0 (none of the time) to 3 (all the time) $(\alpha=.90)$.

\section{Resilience Levers}

Workplace disaster preparedness. Chikoto, Sadiq, and Fordyce's (2012) engagement in disaster preparedness activities questionnaire was used, which assesses whether workplaces have engaged in several disaster preparation activities. Although these activities were not in preparation for COVID-19 specifically, general disaster preparedness may have had an impact when COVID-19 arose. This includes ten questions (e.g., "attended disaster/crisis meetings/training courses outside your organization") measured by "yes" (1) or "no" (0) responses which were then summed $(\alpha=.87)$. These questions were only asked of participants who were recruited through Facebook, as the panel survey had to be shorter in length.

Workplace policy. One item within the Guarding Minds at Work's psychological support subscale (PSR1) was used, which focused on employers offering services or benefits that address mental health (Centre for Applied Research in Mental Health and Addiction, 2018). This was measured on a four-item scale ranging from 1 (strongly disagree) to 4 (strongly agree).

Social capital at work. The eight items (e.g., "we trust our supervisor," "people feel understood and accepted by each other.") of Kouvonen et al.'s (2006) social capital at work scale is measured on a five-item scale ranging from 1 (strongly disagree) to 5 (strongly agree) $(\alpha=.94)$.

The survey also included questions to measure the demographics in Table 1.

\section{Data Analysis}

Descriptive statistics and univariate correlation analysis were examined using the SPSS software (v.27, IBM Corp., 2020). The following inferential analyses were conducted in the Mplus software (v.7.31, Muthén \& Muthén, 2012-2015). For Objective 1, a multiple linear regression was conducted, including demographics and work-related variables as independent variables and job security as the dependent variable. For Objectives 2 and 3, several multiple linear regression models were tested. Each model included job security as an independent variable, a different resilience lever, and the interaction term between these two variables. 
Every model was repeated four times, each time with a different wellbeing outcome. In cases with significant or marginally significant interaction effects, simple slopes (i.e., their biascorrected bootstrap [ $\mathrm{N}=10,000]$ confidence intervals) were examined for the effect of the resilience lever on the wellbeing outcome at the average job security level, and at one standard deviation below and above the mean of job security. All models for Objectives 2 and 3 controlled for personal and work demographics.

\section{Results}

Table 2 presents the descriptives and univariate correlations between the study's variables. Workplace disaster preparedness and workplace policy had larger numbers of missing values. The Full Information Maximum Likelihood approach implemented in Mplus is recognized as one of the best available means to reduce biases related to missing values (Enders, 2010). To reduce biases as much as possible, auxiliary variables (e.g., measure of stress also included in the survey; Cohen, Kamarck, \& Mermelstein, 1983) were added when possible in Mplus ${ }^{2}$ (Enders, 2010). The total number of participants included in the analysis varied from one analysis to another $(n=855-1032)$ because work-related wellbeing variables only applied to participants who were working full-time or part-time, while psychological distress also applied to those temporarily laid off due to COVID-19. In addition, cases with missing values (less than $4 \%$ of applicable cases) on categorical independent variables (e.g., binary demographic variables) could not be considered in the analysis due to their incompatibility with the integration of auxiliary variables in Mplus.

Table 2.

Descriptive statistics and correlations between workers' job security, wellbeing variables and resilience levers $(N=1073)$.

\begin{tabular}{|c|c|c|c|c|c|c|c|c|}
\hline Variable & 1. & 2. & 3. & 4. & 5. & 6. & 7. & 8. \\
\hline 1. Job security & - & & & & & & & \\
\hline \multicolumn{9}{|l|}{ Wellbeing } \\
\hline 2. Troublesome symptoms at work & -.180 & - & & & & & & \\
\hline 3. Impaired productivity at work ${ }^{a}$ & -.182 & .781 & - & & & & & \\
\hline 4. Thriving at work & .270 & -.328 & -.270 & - & & & & \\
\hline 5. Psychological distress & -.237 & .700 & .548 & -.231 & - & & & \\
\hline \multicolumn{9}{|l|}{ Resilience levers } \\
\hline 6. Workplace disaster preparedness ${ }^{b}$ & .228 & -.188 & -.193 & .218 & -.178 & - & & \\
\hline 7. Workplace policy & .323 & -.255 & -.238 & .362 & -.277 & -.304 & - & \\
\hline 8. Social capital at work & .211 & -.266 & -.225 & .493 & -.168 & -.251 & .356 & - \\
\hline$\%$ missing & 2.33 & 0.56 & 0.56 & 0.65 & 0 & 17.19 & 8.48 & 1.58 \\
\hline M & 4.35 & 2.42 & 1.99 & 3.23 & 2.46 & 2.63 & 2.82 & 3.67 \\
\hline$S D$ & 1.36 & 1.06 & .97 & 1.45 & .97 & 2.88 & 1.09 & .91 \\
\hline Theoretical minimum & 1 & 1 & 1 & 0 & 0 & 0 & 1 & 1 \\
\hline Theoretical maximum & 7 & 5 & 5 & 5 & 3 & 10 & 4 & 5 \\
\hline Skewness & -0.22 & 0.45 & 1.10 & -0.66 & 0.17 & -0.96 & -0.48 & -0.66 \\
\hline Kurtosis & -0.48 & -0.76 & 0.73 & -0.58 & -1.20 & -0.15 & -1.07 & 0.17 \\
\hline
\end{tabular}

Note. Correlations between all measures were found to be significant at $\mathrm{p} \leq .001$. ${ }^{\text {aThese }}$ questions were only asked if the participant was working either full- or part-time $(n=887)$. ${ }^{b}$ These questions were only asked to participants recruited through Facebook ( $\mathrm{n}=669)$.

\footnotetext{
${ }^{2}$ Auxiliary variables for missing values were not included when calculating the bootstrapped confidence intervals of the simple slopes given that the Mplus software does not allow for the inclusion of such auxiliary variables when requesting bootstrapping.
} 
As seen in Table 3, workers who have temporarily lost their employment due to COVID-19 perceived significantly lower levels of job security. This was also the case for women (compared to men), people born outside of Canada, those facing higher levels of financial hardship before the crisis, and those employed in the manufacturing sector. In contrast, those employed in health care perceived higher job security.

Table 3.

Regression of job security on personal and work-related demographic variables ( $n=1032)$.

\begin{tabular}{|c|c|c|}
\hline Predictor & $B$ & $\beta$ \\
\hline Age & $0.01^{\mathrm{t}}$ & .05 \\
\hline \multicolumn{3}{|l|}{ Gender } \\
\hline Women vs. men & $-0.37^{* * *}$ & -.12 \\
\hline Non-binary vs. men & $-0.51^{t}$ & -.06 \\
\hline Transgender identity & -0.33 & -.03 \\
\hline Sexual minority & -0.15 & -.05 \\
\hline Living with a disability & -0.04 & -.01 \\
\hline Born outside of Canada & $-0.40^{* * *}$ & -.11 \\
\hline Level of education & -0.01 & -.01 \\
\hline $\begin{array}{l}\text { Number of children in } \\
\text { the household }\end{array}$ & 0.05 & .03 \\
\hline Having temporarily & & \\
\hline $\begin{array}{l}\text { lost their job due to } \\
\text { the COVID-19 crisis }\end{array}$ & $-0.73^{* * *}$ & -.21 \\
\hline $\begin{array}{l}\text { Financial hardship } \\
\text { before the COVID-19 crisis }\end{array}$ & $-0.19^{* * *}$ & -.12 \\
\hline \multicolumn{3}{|l|}{ Sector of employment ${ }^{\mathrm{a}}$} \\
\hline Agriculture & -0.21 & -.02 \\
\hline Automotive & -0.37 & -.04 \\
\hline Construction & -0.40 & -.05 \\
\hline Education & -0.11 & -.03 \\
\hline Electrical & -0.88 & -.04 \\
\hline Food & $-0.37^{\mathrm{t}}$ & -.07 \\
\hline Health care & $0.61^{* * *}$ & .18 \\
\hline Manufacturing & $-0.47^{*}$ & -.08 \\
\hline Mining & -0.58 & -.03 \\
\hline Municipal services & 0.30 & .03 \\
\hline Services & -0.17 & -.04 \\
\hline Transportation & -0.29 & -.04 \\
\hline Other & $-0.31^{*}$ & -.11 \\
\hline
\end{tabular}

Note. $\mathrm{R}^{2}=.19$. aPeople could select more than one employment sector. Each sector was coded as binary (no vs. yes). Given that people selected more than one sector, no reference category was used in the analysis. ${ }^{* * *} \mathrm{p} \leq .001,{ }^{* *} \mathrm{p} \leq .01,{ }^{*} \mathrm{p} \leq .05, \mathrm{t} \mathrm{p} \leq .10$

Table 4 shows the results of multiple regression analyses for the relationships between job security and wellbeing outcomes. Higher job security was related to lower troublesome symptoms, impaired productivity, and psychological distress, as well as to higher thriving at work, when controlling for personal and work-related demographics. 
Table 4.

Regression of job wellbeing outcome variables on job security, resilience levers and their interactions.

\begin{tabular}{|c|c|c|c|c|c|c|c|c|c|c|}
\hline & \multicolumn{2}{|c|}{$\begin{array}{c}\text { Troublesome symptoms at } \\
\text { work }(\mathrm{n}=855)\end{array}$} & \multicolumn{2}{|c|}{$\begin{array}{c}\text { Impaired productivity at } \\
\text { work }(\mathrm{n}=855)\end{array}$} & \multicolumn{3}{|c|}{ Thriving at work $(\mathrm{n}=855)$} & \multicolumn{3}{|c|}{ Distress $(n=1032)$} \\
\hline & $B$ & $95 \% \mathrm{CI} \quad \beta$ & $B$ & $95 \%$ CI $\quad \beta$ & $B$ & $95 \% \mathrm{CI}$ & $\beta$ & $B$ & $95 \%$ CI & $\beta$ \\
\hline \multicolumn{11}{|l|}{ Model 1} \\
\hline Job security & $-0.09^{* *}$ & $-0.137,-0.032-.11$ & $-0.07^{* *}$ & $-0.121,-0.020-.10$ & $0.21^{* * *}$ & $0.137,0.284$ & .19 & $-0.11^{* * *}$ & $-0.153,-0.066$ & -.16 \\
\hline $\begin{array}{l}\text { Disaster } \\
\text { preparedness }\end{array}$ & $-0.44^{* *}$ & $-0.770,-0.117-.13$ & $-0.43^{* *}$ & $-0.730,-0.129-.13$ & $0.55^{*}$ & $0.119,0.973$ & .11 & $-0.27^{t}$ & $-0.546,0.011$ & -.08 \\
\hline Interaction & -0.12 & $-0.350,0.116-.05$ & $-0.19^{t}$ & $-0.407,0.022-.08$ & 0.05 & $-0.255,0.353$ & .01 & -0.13 & $-0.317,0.054$ & -.06 \\
\hline $\mathrm{R}^{2}$ & .21 & & .16 & & .17 & & & .20 & & \\
\hline \multicolumn{11}{|l|}{ Model 2} \\
\hline Job security & $-0.07^{* *}$ & $-0.127,-0.020-.09$ & $-0.06^{*}$ & $-0.113,-0.010-.08$ & $0.14^{* * *}$ & & .12 & $-0.09^{* * *}$ & $-0.135,-0.047$ & -.13 \\
\hline $\begin{array}{l}\text { Workplace } \\
\text { policy }\end{array}$ & $-0.15^{* * *}$ & $-0.212,-0.078-.15$ & $-0.14^{* * *}$ & $-0.204,-0.075-.15$ & $0.44^{* * *}$ & $0.345,0.526$ & .32 & $-0.13^{* * *}$ & $-0.189,-0.080$ & -.16 \\
\hline Interaction & $-0.07^{* *}$ & $-0.112,-0.019-.09$ & $-0.06^{*}$ & $-0.103,-0.012-.09$ & 0.00 & $-0.064,0.063$ & .00 & $-0.06^{* *}$ & $-0.092,-0.019$ & -.09 \\
\hline $\mathrm{R}^{2}$ & .21 & & .16 & & .24 & & & .21 & & \\
\hline \multicolumn{11}{|l|}{ Model 3} \\
\hline Job security & $-0.06^{*}$ & $-0.112,-0.009-.08$ & $-0.05^{*}$ & $-0.104,-0.003-.07$ & $0.13^{* * *}$ & $0.064,0.197$ & .12 & $-0.10^{* * *}$ & $-0.143,-0.055$ & -.14 \\
\hline $\begin{array}{l}\text { Social capital } \\
\text { at work }\end{array}$ & $1-0.29^{* * *}$ & $-0.358,-0.214-.25$ & $-0.24^{* * *}$ & $-0.306,-0.168-.22$ & $0.71^{* * *}$ & $0.622,0.806$ & .45 & $-0.12^{* * *}$ & $-0.182,-0.062$ & -.12 \\
\hline Interaction & $-0.06^{*}$ & $-0.111,-0.010-.07$ & $-0.07^{* *}$ & $-0.116,-0.018-.09$ & 0.02 & $-0.041,0.088$ & .02 & $-0.05^{*}$ & $-0.086,-0.005$ & -.06 \\
\hline $\mathrm{R}^{2}$ & .24 & & .18 & & .34 & & & .20 & & \\
\hline
\end{tabular}

Note. $95 \%$ CI refers to the $95 \%$ confidence interval of the unstandardized estimates. The results were obtained controlling for: age, gender, identifying as transgender, sexual minority, living with disabilities, born outside of Canada, level of education, number of children in the household and financial hardship before the COVID-19 crisis. For the distress-related analysis, having temporarily lost your job due to the COVID-19 crisis was also included as a control.

${ }^{* * *} \mathrm{p} \leq .001,{ }^{* *} \mathrm{p} \leq .01,{ }^{*} \mathrm{p} \leq .05, \mathrm{t} \mathrm{p} \leq .10$.

As shown in Table 4, the main effects of workplace disaster preparedness were significant and negative on troublesome symptoms and impaired productivity, and positive on thriving at work. Its effect was marginally significant and negative on distress. Further, for impaired productivity, the interaction effect between workplace disaster preparedness and job security was marginally significant. The main effects of both workplace policy and social capital at work were significant and negative on troublesome symptoms, impaired productivity and distress, and significant and positive on thriving at work. The interaction effects of these two resilience levers with job security were significant on all wellbeing outcomes, except thriving at work. 
Table 5.

Simple slopes of the effect of resilience levers on wellbeing outcomes at multiple levels of job security.

\begin{tabular}{cccccccc}
\hline & $\begin{array}{c}\text { Troublesome } \\
\text { symptoms at work } \\
(\mathrm{n}=855)\end{array}$ & $\begin{array}{c}\text { Impaired productivity } \\
\text { at work (n=855) }\end{array}$ & $\begin{array}{c}\text { Thriving at work } \\
(\mathrm{n}=855)\end{array}$ & $\begin{array}{c}\text { Distress } \\
(\mathrm{n}=1032)\end{array}$ \\
\hline$B$ & $95 \% \mathrm{CI}$ & $B$ & $95 \% \mathrm{CI}$ & $B$ & $95 \% \mathrm{CI}$ & $B$ & $95 \% \mathrm{CI}$ \\
\hline
\end{tabular}

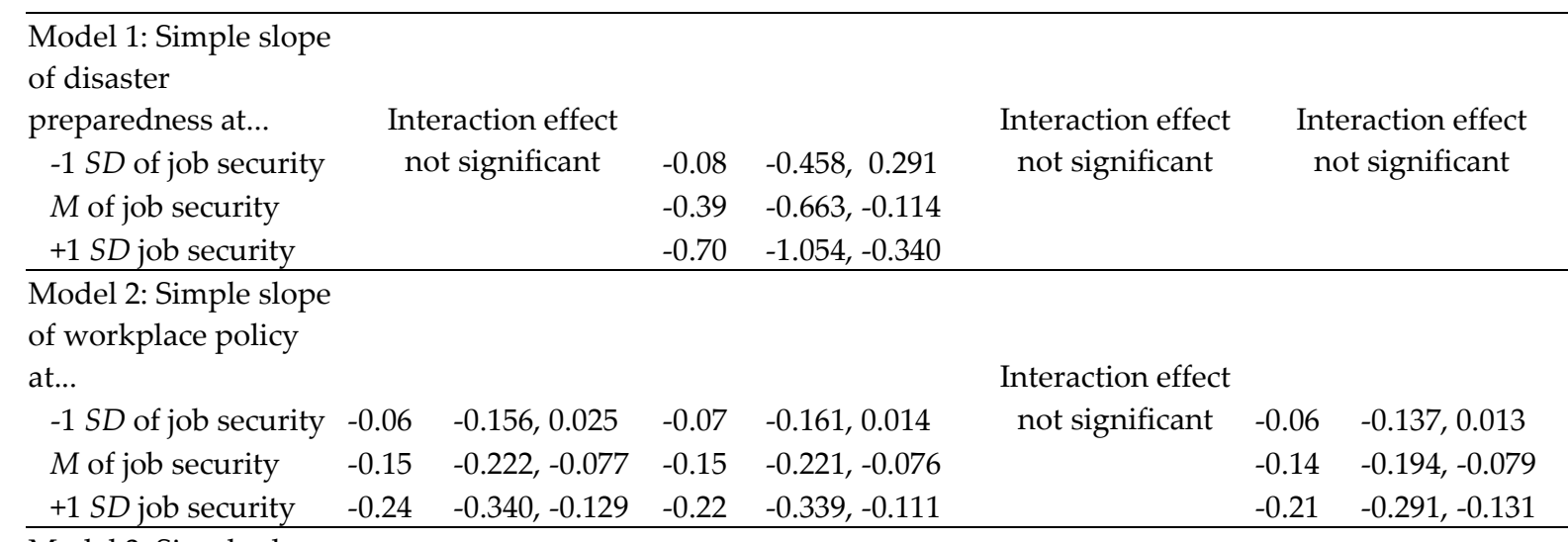

Model 3: Simple slope

of workplace social

capital at work at...

\begin{tabular}{llllllll}
-1 SD of job security & -0.21 & $-0.316,-0.109$ & -0.15 & $-0.256,-0.047$ & not significant & -0.06 & $-0.140,0.020$ \\
$M$ of job security & -0.29 & $-0.371,-0.214$ & -0.24 & $-0.321,-0.161$ & & -0.12 & $-0.185,-0.057$ \\
$+1 S D$ job security & -0.37 & $-0.482,-0.261$ & -0.33 & $-0.444,-0.217$ & & -0.18 & $-0.276,-0.095$ \\
\hline
\end{tabular}

Note. $95 \%$ CI refers to the $95 \%$ bias-corrected bootstrap $(\mathrm{N}=10,000)$ confidence interval of the unstandardized estimates. The results were obtained controlling for: age, gender, identifying as transgender, sexual minority, living with disabilities, born outside of Canada, level of education, number of children in the household and financial hardship before the COVID-19 crisis. For the distress-related analysis, having temporarily lost your job due to the COVID-19 crisis was also included as a control. ${ }^{* * *} \mathrm{p} \leq .001,{ }^{* *} \mathrm{p} \leq .01,{ }^{*} \mathrm{p} \leq .05$.

As shown in Table 5, the simple slopes of 1) workplace disaster preparedness on impaired productivity, 2) workplace policy on troublesome symptoms, impaired productivity and distress, and 3) workplace social capital on distress, were all significant only at moderate and high levels of job security. The simple slopes of workplace social capital on troublesome symptoms and on impaired productivity were significant at the three levels of job security; however, the estimates suggest that the effects were larger when job security was higher.

\section{Discussion}

Job security is not only associated with lower negative wellbeing during the COVID-19 crisis, but it also seems to foster the actualization of one's potential at work. Sample means on the wellbeing variables were relatively moderate, except for distress, for which the average was between the highest and second highest point on the scale. This is consistent with Statistics Canada's (2020a) findings indicating that among 46,000 Canadians survey participants, 52\% reported that their mental health has worsened since the beginning of social distancing. In contrast, impacts of the crisis on positive wellbeing (e.g., thriving at work) may be delayed; it is possible the measurement scale of positive wellbeing was not sensitive enough to change, given its focus was on the last four weeks while the crisis had amplified only two weeks before data collection.

On average, the levels of job security seemed to be only moderate, i.e., at the neutral point on the measurement scale. A study in China has underlined the negative impacts of media exposure 
during the COVID-19 pandemic (Gao et al., 2020); along these lines, participants in our sample may have been exposed to media content related to job loss, which may have contributed to feelings of insecurity. Participants who were temporarily laid off due to COVID-19 also reported lower job security, which indicates that their sense of job security might have been fragilized by unemployment even if they expected to regain their employment after the crisis.

Aligned with previous research (see review by Landsbergis et al., 2014), groups usually found to experience inequities (i.e., with lower income, newcomers) reported lower levels of job security, which could lead to further disparities in wellbeing. These findings are consistent with Van Wagner's (2018) study which exemplified how marginalized workers (e.g., people of Chinese or Southeast Asian descent, undocumented workers, and immigrants), experienced a higher degree of job insecurity during the SARS outbreak in Toronto, Canada. The COVID-19 crisis is likely leading to a series of compounding stressors faced by marginalized groups. Job insecurity, shown to be associated with lower wellbeing more generally (Witte, 2010), is only one of the multiple stressors threatening their wellbeing. In addition, marginalized workers' wellbeing is also likely negatively impacted (as it is the case for other people too) by the fear of contracting the COVID-19 virus (Holmes et al., 2020; Zhou et al., 2020).

Furthermore, marginalized workers from some subgroups (i.e., newcomers) may be experiencing negative effects of racism and xenophobia. Many people of East Asian descent have reported experiences of increased racism and xenophobia during the current COVID-19 crisis (Balvaneda, Roemer, Hayes-Skelton, Yang, \& Ying, n.d.). In a study that analyzed the topics discussed on a social media platform - Twitter - during the pandemic, increased racism was among the most prevalent topics, including postings referring to rude comments and dirty looks against people of East Asian descent (Abd-Alrazaq et al., 2020). As both racism and xenophobia are associated with poorer physical and mental wellbeing (Paradies et al., 2015; Suleman, Garber, \& Rutkow, 2018), migrant workers from East Asian descent, in particular, may face long-term wellbeing consequences that persist after the pandemic. To address these multiple stressors, it is evident that many longer-term systematic changes must occur both within society and the workplace. Ensuring job security is one of the ways stakeholders (e.g., policymakers, employers) can support the wellbeing of marginalized workers by providing a stable occupational and economical foundation that can help them cope with the other stressors experienced during the current crisis.

Findings suggest that the considered resilience levers are beneficial in the workplace as they were overall associated with better wellbeing outcomes, consistently with previous literature (Attridge, 2012, Hamouche, 2020, Kouvonen et al., 2006). It is useful to consider these levers on a continuum that straddle the diverse workplace wellbeing interventions approaches (LaMontagne et al., 2014, 2019), from promotion (social capital increase) and prevention (organizational disaster preparedness), to treatment of wellbeing issues (employee assistance programs). The effects of resilience levers were stronger and more consistent at moderate and high job security levels. It may be the case that in the current context, the lives of workers with lower job security is impacted by the crisis to such a degree that these resilience levers are not powerful enough. Another interpretation is that for resilience levers to be beneficial, lower order, safety needs must first be met, in concordance with Maslow's (1943) work. In addition to the existing financial assistance provided by the Canadian government to workers impacted by COVID-19 (i.e., Canada Emergency Response Benefit [CERB]), several measures can be taken to increase the job security of workers. This may involve implementing policies that protect workers who miss work due to reasons related to COVID-19 (e.g., experiencing symptoms or undergoing 
the process of testing for COVID-19). These policies may include, for example, providing sickness benefits and a job-protected leave of absence (Office of the Premier, 2020).

Beyond the importance of promoting job security, our findings also point to the usefulness of interventions focused on optimizing social capital, workplace disaster preparedness, and workplace policy. Social media could be utilized to potentially increase social capital through peer-to-peer communication (Erikson, 2011). For instance, workers would have a platform to discuss their concerns and experiences, as well as to share knowledge and resources related to the pandemic. This may serve as a way to validate workers' feelings and to help them feel more connected with other workers during pandemic times. Improved communication in the workplace has been associated with enhanced social capital (Meng et al., 2019). From that perspective, employers should utilize social media and other tools (i.e., online meeting platforms) to improve communication with their workers, specifically about the impacts of the crisis on the status of their current and future employment (Sinclair et al., 2020); such open communication could contribute to social capital, while also reducing feelings of job insecurity.

A study on the mental health impacts of the SARS outbreak in Toronto using a sample from the general population (but including a large proportion of health care workers) suggests that long periods of quarantine could lead to developing post-traumatic stress symptoms (Hawryluck et al., 2004). Thus, as part of the workplace disaster preparedness plan for future pandemics, it is important for workplaces to be equipped with or to provide employees with access to traumafocused counselling resources. In addition, employers should provide ongoing training to managers and supervisors on supporting employees who experience mental health challenges in safely continuing their work or returning to work when they are ready - if they need to take a leave. Finally, adequate benefit plans, including free access to appropriate treatments (e.g., telehealth services), may help reduce mental health-related absenteeism, poor performance, and concerns about job security (Cooper \& Dewe, 2008; Zhou et al., 2020).

\section{Limitations}

The findings are based on a convenience sample and are not representative of all Canadian workers, including specifically those in precarious forms of employment. Definite conclusions cannot be made related to the directionality of the relationships found.

The recency of the crisis may have influenced our findings, and time may allow workers to develop resilience. In addition, the brief scales used in the survey and some variables' missing data may have impacted the findings.

While the study provides evidence of elevated levels of job insecurity among minority or marginalized workers in the context of the COVID-19 crisis, this finding needs to be replicated and deepened by using larger samples or by oversampling multiple minority/marginalized subgroup of the population, given the relatively small representation of some of these workers in the current study. Larger representation of marginalized groups would allow for future analysis to be conducted to better understand similarities and differences between the wellbeing of these groups in the context of pandemics, and to consider the intersectional effects (Bauer \& Scheim, 2029) of belonging to multiple marginalized groups.

\section{Conclusion}

The results show the importance of considering systemic changes to better support the job security of workers during a pandemic, especially to address the needs of marginalized groups (e.g., women, migrants). Workplace leaders are encouraged to communicate with their workers to foster trust (Ugboro, 2016) and reassure them that their jobs are secure (Vineburgh, Gifford, 
Ursano, Fullerton, \& Benedek, 2007). Without employment security as a stable base, workplacerelated interventions targeting work resilience levers may not reach an optimal impact. As such, interventions targeting organizational disaster preparedness, policy and social capital need to be considered as part of broader systemic efforts (Bone, 2015).

The current times are stressful and dire for all of us, but as shown in the study, the situation is even harder for marginalized individuals, which were already facing unfair negative living and working conditions to start with. Unfortunately, most of the practical recommendations that have emerged so far from positive psychology and related fields of research and intervention have focused on individual- or small group-focused interventions that do not address the systemic (e.g., economic, political, socio-cultural) causes of lower wellbeing levels experienced by these individuals (see Martínez \& Di Martino, 2018; Prilleltensky, 2018). As Prilltelentsky eloquently stated (2018, p. xxi), "in the absence of fair and just conditions, the potential benefits of positive psychology will remain within the province of the privileged". The global, unprecedented nature of the current COVID-19 crisis calls for global changes in our way of thinking about and promoting the wellbeing of workers as well as other people so we better serve the public interest and achieve a greater societal impact. By better centring the needs of the most marginalized segments of the population, we can partner with them to develop and test interventions that serve the purpose of providing them fairer and life-enhancing work and living conditions.

Addressing large scale social conditions such as job insecurity, public health crises and systemic xenophobia is not necessarily "in the traditional wheelhouse" of psychologists, human resource managers and employers. Thus, we hope the current crisis and its profound societal impacts will serve as a catalyst to further the collaboration across disciplines and stakeholders. As exemplified by our multidisciplinary framework, the collaboration between public health policymakers, occupational health professionals, workplace leaders, psychologists and political decision-makers may be valuable to help address the complex systemic issues of workers' wellbeing during COVID-19. Collaboration is important to comprehensively support the wellbeing of workers, including that of people who risk their wellbeing to keep our countries safe and provide us with essential services in these times.

\section{Author's Note}

We would like to acknowledge and thank the workers who, despite the hardships they have experienced during the COVID-19 pandemic, took part in our study so that we may aid in understanding how to better support Canadian workers during times of crises. Furthermore, we would also like to thank our research assistants (Ashley Gooderham, Isabel Zagazeta, and Jessica Foster) and Sarah Ranco for their help at different stages of this study.

This research was financially supported by Wilfrid Laurier University and the Social Science and Humanities Research Council of Canada's General Research Fund.

\section{Authors}

Tyler Pacheco

Wilfrid Laurier University

tpacheco@wlu.ca

Simon Coulombe

Wilfrid Laurier University 
Christine Khalil

Wilfrid Laurier University

Sophie Meunier

Université du Québec à Montréal

Marina Doucerain

Université du Québec à Montréal

Emilie Auger

University of Waterloo

Emily Cox

Wilfrid Laurier University

Publishing Timeline

Received 22 June 2020

Accepted 28 July 2020

Published 13 August 2020

\section{References}

Abd-Alrazaq, A., Alhuwail, D., Househ, M., Hamdi, M., \& Shah, Z. (2020). Top concerns of tweeters during the COVID-19 pandemic: Infoveillance study. Journal of Medical Internet Research, 22(4). doi: $10.2196 / 19016$

Attridge, M. (2012). Employee assistance programs: Evidence and current trends. In R. J. Gatchel \& I. Z. Schultz (Eds.), Handbook of occupational health and wellness (pp. 441-467). Boston, MA: Springer.

Balvaneda, B., Roemer, L., Hayes-Skelton, S., Yang, A., \& Ying, A. (n.d.). Responding to racism during the COVID-19 outbreak. Retrieved from: https://adaa.org/learn-from-us/from-the-experts/blogposts/consumer/responding-racism-during-covid-19-outbreak

Bauer, G. R., \& Scheim, A. I. (2019). Advancing quantitative intersectionality research methods: Intracategorical and intercategorical approaches to shared and differential constructs. Social Science \& Medicine, 226, 260-262. doi: 10.1016/j.socscimed.2019.03.018

Blacker, A., Dion, S., Grossmeier, J., Hecht, R., Markle, E., Meyer, L., ... Wolfe, E. (2020). Social determinants of health - an employer priority. American Journal of Health Promotion, 34(2), 207-215. doi: $10.1177 / 0890117119896122 b$

Bone, K. D. (2015). The Bioecological Model: Applications in holistic workplace well-being management. International Journal of Workplace Health Management, 8(4), 256-271. doi: 10.1108/IJWHM-04-20140010

Carter, D. P., \& May, P. J. (2020). Making sense of the US COVID-19 pandemic response: A policy regime perspective. Administrative Theory \& Praxis, 42(2), 1-13. doi: 10.1080/10841806.2020.1758991

Centre for Applied Research in Mental Health and Addiction. (2018). Know the psychosocial factors. Retrieved from: https://guardingmindsatwork.ca/about/about-psychosoclial-factors.

Chikoto, G. L., Sadiq, A. A., \& Fordyce, E. (2013). Disaster mitigation and preparedness: Comparison of nonprofit, public, and private organizations. Nonprofit and Voluntary Sector Quarterly, 42(2), 391410. doi: $10.1177 / 0899764012452042$

Cohen, S., Kamarck, T., \& Mermelstein, R. (1983). A global measure of perceived stress. Journal of Health and Social Behavior, 24(4), 385-396. doi: 10.2307/2136404 
Cooper, C., \& Dewe, P. (2008). Well-being-absenteeism, presenteeism, costs and challenges. Occupational Medicine, 58(8), 522-524. doi: 10.1093/occmed/kqn124

Dagenais-Desmarais, V., \& Savoie, A. (2012). What is psychological well-being, really? A grassroots approach from the organizational sciences. Journal of Happiness Studies, 13(4), 659-684. doi: 10.1007/s10902-011-9285-3

Enders, C. K. (2010). Applied missing data analysis. New York, NY: Guilford Press.

Erickson, L. B. (2011). Social media, social capital, and seniors: The impact of Facebook on bonding and bridging social capital of individuals over 65. Proceedings of the Seventeenth Americas Conference on Information Systems. Retrieved from:

https://pdfs.semanticscholar.org/e45d/782b985c3b72a4c4174e29da0da0760b9675.pdf

Fisher, C. D. (2014). Conceptualizing and measuring wellbeing at work. In P. Y. Chen, \& C. L. Cooper (Eds.), Wellbeing: A Complete Reference Guide, Work and Wellbeing, Vol. III, (pp. 9-33). Hoboken, N.J.: John Wiley \& Sons.

Fung, O. W., Loke, A. Y., \& Lai, C. K. (2008). Disaster preparedness among Hong Kong nurses. Journal of Advanced Nursing, 62(6), 698-703. doi: 10.1111/j.1365-2648.2008.04655.x

Fullerton, A. S., McCollum, D. B., Dixon, J. C., \& Anderson, K. F. (2020). The insecurity gradient in health: How inequality in the distribution of job insecurity matters for the relationship between job insecurity and self-rated health in Europe. Sociological Quarterly, 61(1), 107-127. doi: 10.1080/00380253.2019.1581038

Gao, J., Zheng, P., Jia, Y., Chen, H., Mao, Y., Chen, S., ... \& Dai, J. (2020). Mental health problems and social media exposure during COVID-19 outbreak. Plos One, 15(4), 1-10.

Gupta, A. G., Moyer, C. A., \& Stern, D. T. (2005). The economic impact of quarantine: SARS in Toronto as a case study. Journal of Infection, 50(5), 386-393. doi: 10.1016/j.jinf.2004.08.006

Hamouche, S. (2020). COVID-19 and employees' mental health: stressors, moderators and agenda for organizational actions. Emerald Open Research, 2(15). doi: 10.1371/journal.pone.0231924

Harter, J. K., Schmidt, F. L., \& Keyes C. L. M. (2003). Well-being in the workplace and its relationship to business outcomes: a review of the Gallup studies. In C. L. M. Keyes \& J. Haidt (Eds.), Flourishing: Positive psychology and the life well-lived (pp. 206). Washington, D. C.: American Psychological Association.

Hawryluck, L., Gold, W. L., Robinson, S., Pogorski, S., Galea, S., \& Styra, R. (2004). SARS control and psychological effects of quarantine, Toronto, Canada. Emerging Infectious Diseases, 10(7), 1206. doi: 10.3201/eid1102.040760

Holmes, E. A., O'Connor, R. C., Perry, V. H., Tracey, I., Wessely, S., Arseneault, L., ... \& Ford, T. (2020). Multidisciplinary research priorities for the COVID-19 pandemic: A call for action for mental health science. The Lancet Psychiatry, 7, 547-560. doi: 10.1016/S2215-0366(20)30168-1

Jahoda, M. (1982). Employment and unemployment: A social-psychological analysis. Cambridge, England: CUP Archive.

Jones, S. N. (2020). Communicate clear expectations to keep work-life boundaries in place during COVID-19. Retrieved from: https://www.cpacanada.ca/en/news/atwork/2020-04-23-work-life-boundaries

Keyes, C. L. (2002). The mental health continuum: From languishing to flourishing in life. Journal of Health and Social Behavior, 207-222, 43(2), 207-222. doi: 10.2307/3090197

Keyes, C. L. (2005). Mental illness and/or mental health? Investigating axioms of the complete state model of health. Journal of Consulting and Clinical Psychology, 73(3), 539-548. doi: 10.1037/0022006X.73.3.539 
Keyes, C. L. (2006). Subjective well-being in mental health and human development research worldwide: An introduction. Social Indicators Research, 77(1), 1-10. doi: 10.1007/s11205-005-5550-3

Kouvonen, A., Kivimäki, M., Vahtera, J., Oksanen, T., Elovainio, M., Cox, T., ... \& Wilkinson, R. G. (2006). Psychometric evaluation of a short measure of social capital at work. BMC Public Health, 6(1). doi: 10.1186/1471-2458-6-251

Kraimer, M. L., Wayne, S. J., Liden, R. C., \& Sparrowe, R. T. (2005). The role of job security in understanding the relationship between employees' perceptions of temporary workers and employees' performance. Journal of Applied Psychology, 90(2), 389-398. doi: 10.1037/00219010.90.2.389

Kroenke, K., Spitzer, R. L., Williams, J. B., \& Löwe, B. (2009). An ultra-brief screening scale for anxiety and depression: The PHQ-4. Psychosomatics, 50(6), 613-621. doi: 10.1016/S0033-3182(09)70864-3

Lam, R. W., Michalak, E. E., \& Yatham, L. N. (2009). A new clinical rating scale for work absence and productivity: Validation in patients with major depressive disorder. BMC Psychiatry, 9(1), 1-7. doi: 10.1186/1471-244X-9-78

LaMontagne, A. D., Martin, A., Page, K. M., Reavley, N. J., Noblet, A. J., Milner, A. J., ... \& Smith, P. M. (2014). Workplace mental health: developing an integrated intervention approach. BMC Psychiatry, 14(1), 1-11. doi: 10.1186/1471-244X-14-131

LaMontagne, A. D., Martin, A., Page, K. M., Reavley, N. J., Noblet, A. J., Milner, A. J., ... \& Smith, P. M. (2019). Developing an integrated approach to workplace mental health. In H. L. Hudson, J. A. S. Nigam, S. L. Sauter, L. C. Chosewood, A. L. Schill, \& J. Howard (Eds.), Total worker health (p. 211227). Washington, D. C.: American Psychological Association.

Landsbergis, P. A., Grzywacz, J. G., \& LaMontagne, A. D. (2014). Work organization, job insecurity, and occupational health disparities. American Journal of Industrial Medicine, 57(5), 495-515. doi: 10.1002/ajim.22126

Lu, C. Q., Du, D. Y., Xu, X. M., \& Zhang, R. F. (2017). Revisiting the relationship between job demands and job performance: The effects of job security and traditionality. Journal of Occupational and Organizational Psychology, 90(1), 28-50. doi: 10.1111/joop.12158

Martínez, R. S., \& Di Martino, S. (2018). Community social psychology and positive psychology: Learning from the experience of Latin America. In Brown, N. J. L., Lomas, T., \& Eiroa-Orosa, F. J. (Eds.), The Routledge International Handbook of Critical Positive Psychology (pp. 409-420). New York, N. Y.: Routledge.

Maslow, A. H. (1943). A theory of human motivation. Psychological Review, 50(4), 370-396.

Mastroianni, A. C. (2009). Slipping through the net: Social vulnerability in pandemic planning. Hastings Center Report, 39(5), 11-12. doi: 10.1353/hcr.0.0186

Mckay, T., Henne, J., Gonzales, G., Quarles, R., \& Garcia, S. (2020). The impact of COVID-19 on LGBTQ Americans. Retrieved from: https://www.asafenashville.org/wp-content/ uploads/2020/05/Brief_COVID_LGBTQ_Americans.pdf

McLarnon, M. J., \& Rothstein, M. G. (2013). Development and initial validation of the workplace resilience inventory. Journal of Personnel Psychology, 12, 63-73. doi: 10.1027/1866-5888/a000084

Nicola, M., Alsafi, Z., Sohrabi, C., Kerwan, A., Al-Jabir, A., Iosifidis, C., ... \& Agha, R. (2020). The socioeconomic implications of the coronavirus pandemic (COVID-19): A review. International Journal of Surgery, 78, 185. doi: 10.1016/j.ijsu.2020.04.001

Okechukwu, C. A., El Ayadi, A. M., Tamers, S. L., Sabbath, E. L., \& Berkman, L. (2012). Household food insufficiency, financial strain, work-family spillover, and depressive symptoms in the working 
class: The work, family, and health network study. American Journal of Public Health, 102(1), 126133. doi: 10.2105/AJPH.2011.300323

Office of the Premier. (2020, March 16). Premier Ford Announces Job Protection for Workers during the COVID-19 Situation. Ontario. Retrieved from: https://news.ontario.ca/opo/en/ 2020/03/premier-ford-announces-job-protection-for-workers-during-the-covid-19-situation.html

Paradies, Y., Ben, J., Denson, N., Elias, A., Priest, N., Pieterse, A., ... \& Gee, G. (2015). Racism as a determinant of health: A systematic review and meta-analysis. PLoS ONE, 10(9), 1-48. doi: 10.1371/journal.pone.0138511

Perry, R. W., Lindell, M. K., \& Tierney, K. J. (2001). Facing the unexpected: Disaster preparedness and response in the United States. Washington, D. C.: Joseph Henry Press.

Prilltelentsky, I. (2018). Foreword: interiorizing and interrogating well-being. In Brown, N. J. L., Lomas, T., \& Eiroa-Orosa, F. J. (Eds.), The Routledge International Handbook of Critical Positive Psychology (pp. 409-420). New York, N. Y.: Routledge.

Qin, X., \& Jiang, Y. (2011). The impact of natural disaster on absenteeism, job satisfaction, and job performance of survival employees: An empirical study of the survivors in Wenchuan earthquake. Frontiers of Business Research in China, 5(2), 219-242. doi: 10.1007/s11782-010-0129-0

Rosenblatt, Z., \& Ruvio, A. (1996). A test of a multidimensional model of job insecurity: The case of Israeli teachers. Journal of Organizational Behavior, 17(S1), 587-605. doi: 0894-3796/96/SI0587-19

Rothstein, M. A., \& Coughlin, C. N. (2019). Ensuring compliance with quarantine by undocumented immigrants and other vulnerable groups: Public health versus politics. American Journal of Public Health, 109(9), 1179-1183. doi: 10.2105/AJPH.2019.305201

Rothstein, M. A., \& Talbott, M. K. (2007). Encouraging compliance with quarantine: A proposal to provide job security and income replacement. American Journal of Public Health, 97(S1), S49-S56. doi: 10.2105/AJPH.2006.097303

Sanchez, D. G., Parra, N. G., Ozden, C., \& Rijkers, B. (2020). Which jobs are most vulnerable to COVID-19? What an analysis of the European union reveals. Retrieved from: http://documents.worldbank.org/curated/en/820351589209840894/Which-Jobs-Are-MostVulnerable-to-COVID-19-What-an-Analysis-of-the-European-Union-Reveals

Selenko, E., \& Batinic, B. (2013). Job insecurity and the benefits of work. European Journal of Work and Organizational Psychology, 22(6), 725-736. doi: 10.1080/1359432X.2012.703376

Statistics Canada. (2020a). Canadians' mental health during the COVID-19 pandemic. Ottawa, Canada: Statistics Canada. Retrieved from: https://www150.statcan.gc.ca/n1/dailyquotidien/200527/dq200527b-eng.htm

Statistics Canada. (2020b). Canadian Perspectives Survey Series 1: Impacts of COVID-19 on job security and personal finances. Ottawa, Canada: Statistics Canada. Retrieved from: https://www150.statcan.gc.ca/n1/daily-quotidien/200420/dq200420b-eng.htm

Steel, P., Schmidt, J., Bosco, F., \& Uggerslev, K. (2019). The effects of personality on job satisfaction and life satisfaction: A meta-analytic investigation accounting for bandwidth- fidelity and commensurability. Human Relations, 72(2), 217-247. doi: 10.1177/0018726718771465

Suleman, S., Garber, K. D., \& Rutkow, L. (2018). Xenophobia as a determinant of health: An integrative review. Journal of Public Health Policy, 39, 407-423. doi: 10.1057/s41271-018-0140-1

Tennant, R., Hiller, L., Fishwick, R., Platt, S., Joseph, S., Weich, S., ... \& Stewart-Brown, S. (2007). The Warwick-Edinburgh Mental Well-being Scale (WEMWBS): Development and UK validation. Health and Quality of life Outcomes, 5(1), 63. doi: 10.1186/1477-7525-5-63 
Ugboro, I. O. (2016). Influence of managerial trust on survivors' perceptions of job insecurity and organizational commitment in a post restructuring and downsizing environment. Journal of Behavioral and Applied Management, 4(3), 231-265. Retrieved from: https://jbam.scholasticahq.com/article/1077-influence-of-managerial-trust-on-survivorsperceptions-of-job-insecurity-and-organizational-commitment-in-a-post-restructuring-anddownsizing-environment

Upadhyay, U. T., \& Arya, S. (2015). A critique of research studies on application of positive psychology for augmenting children's emotional wellbeing. Indian Journal of Positive Psychology, 6(4), 417. doi: 10.1007/s11469-019-00169-z

Van Wagner, E. (2008). The practice of biosecurity in Canada: Public health legal preparedness and Toronto's SARS crisis. Environment and Planning A: Economy and Space, 40(7), 1647-1663. doi: $10.1068 / \mathrm{a} 40281$

Veenhoven, R. (2000). The four qualities of life. Journal of Happiness Studies, 1(1), 1-39. doi: 10.1023/A:1010072010360

Vineburgh, N. T., Gifford, R. K. Ursano, R. J., Fullerton, C. S., \& Benedek, D. M. (2007). Workplace disaster preparedness and response. In Ursano, R. J., Fullerton, C. S., Weisaeth, L., Raphael, B. (Eds.), Textbook of Disaster Psychiatry, (pp. 265-283). Cambridge, United Kingdom: Cambridge University Press.

Wilkinson, R. G., \& Marmot, M. (Eds.). (2003). Social determinants of health: The solid facts. Genève, Switzerland: World Health Organization.

Wilson, J. M., Lee, J., Fitzgerald, H. N., Oosterhoff, B., Sevi, B., \& Shook, N. J. (2020). Job insecurity and financial concern during the COVID-19 pandemic are associated with worse mental health. Journal of Occupational and Environmental Medicine. doi: 10.1097/JOM.0000000000001962

Witte, H. D. (1999). Job insecurity and psychological well-being: Review of the literature and exploration of some unresolved issues. European Journal of Work and Organizational Psychology, 8(2), 155-177. doi: 10.1080/135943299398302

World Health Organization. (2017). A strategic framework for emergency preparedness. Retrieved from: https://extranet.who.int/sph/sites/default/files/document-library/document/ Preparedness-9789241511827-eng.pdf

Workplace Safety and Insurance Board. (2018). Industry. Retrieved from: http://www.wsibstatistics.ca/S1/Industry\%20\%20WSIB\%20By\%20The\%20Numbers_P.php.

Zhou, X., Snoswell, C. L., Harding, L. E., Bambling, M., Edirippulige, S., Bai, X., \& Smith, A. C. (2020). The role of telehealth in reducing the mental health burden from COVID-19. Telemedicine and eHealth, 26(4), 377-379. doi: 10.1089/tmj.2020.0068 